\title{
Study About the Development of the Temporomandibular Joint in the Human Fetuses
}

\author{
Estudio del Desarrollo de la Articulación Témporomandibular en Fetos Humanos
}

\author{
Nilton Alves
}

\begin{abstract}
ALVES, N. Study about the development of the temporomandibular joint in the human fetuses. Int. J. Morphol., 26(2):309-312, 2008.
SUMMARY: The temporomandibular joint (TMJ) is a highly specialized articulation that differs from all the other synovial articulations for many reasons. In children, different from what we observe in adults, these articulations have rarely been studied under the morphofunctional aspect, mainly in the embryonary and fetal stages. In this study 10 fetuses with ages varying from 16 to 39 weeks of intrauterine life were used, and it could be observed that the fibers and thickness of the articular disc, as well as the articular capsule and the condylar process, suffer modifications according to age. It was also observed that the superior head of the lateral pterygoid muscle inserts itself in the articular disc and capsule in all the ages studied. Also, the maturation of the articular tissues, especially of the articular disc, as well as, the associated muscles, suggests that the TMJ was able to carry out mandibular movements since the $24^{\text {th }}$ week of intrauterine life.
\end{abstract}

KEY WORDS: Temporomandibular joint; Embryonary development; Fetal development.

\section{INTRODUCTION}

The temporomandibular joint (TMJ) is a highly specialized articulation that differs from all the other synovial articulations for several reasons. To understand this, it is sufficient to remember that when we examine a TMJ we should always examine the contralateral because an alteration affects this one too, in a certain way, as well as, the muscles involved in the mandibular movements, teeth and periodont and sometimes even the structures of the cervical region (Alves \& Cândido, 2007). It has been the subject of several studies, once each day there are more patients suffering from temporomandibular malfunctions. However, in children, differently from the adults, these articulations have rarely been studied when considering the morphofunctional aspect, mainly in the fetal and embryonary stage. The objective of this study was to observe the morphological alterations that occurred in the TMJ in fetuses with age varying between 16 and 39 weeks of intrauterine life.

\section{MATERIAL AND METHOD}

In this work 10 fetuses ranging in age from 16 to
39 weeks of intrauterine life were studied, being six male and four female, fixed with formaldehyde, belonging to Department of Morphology of the School of Dentistry of Araraquara, UNESP, Brazil.

The blocks studied were obtained as follows: First, a horizontal incision along the superior edge of the zygomatic arc was done, followed by a descending daily pre-auricular incision guided by the posterior edge of the mandibles branch until its angle stood out. After that, the parotid gland was removed and detached the masseter muscle. After the osteotomy of the zygomatic arc, as well as, the one of coronoid process, the temporal muscle was removed, exposing the TMJ and the lateral pterygoid muscle.

By doing this, the blocks with the mandibular fossa, the articular disc, the mandible condyle, the articular capsule and posterior third of the lateral pterygoid muscle were obtained, with both the heads. The blocks of the right side had suffered sagital cuts, and of the left side, transversal cuts, with thickness of $20 \mu \mathrm{m}$, and were colored by the Azo Carmin method for analysis in optic microscopy. 


\section{RESULTS}

The articular disc was well defined since the youngest fetuses. It presented a fibrous connective tissue with a predominantly compact aspect, standing out from the articular capsula due to the presence of fibers of different aspects. These fibers were more sinuous at a younger age and more stretched in an older age (Fig. 1).

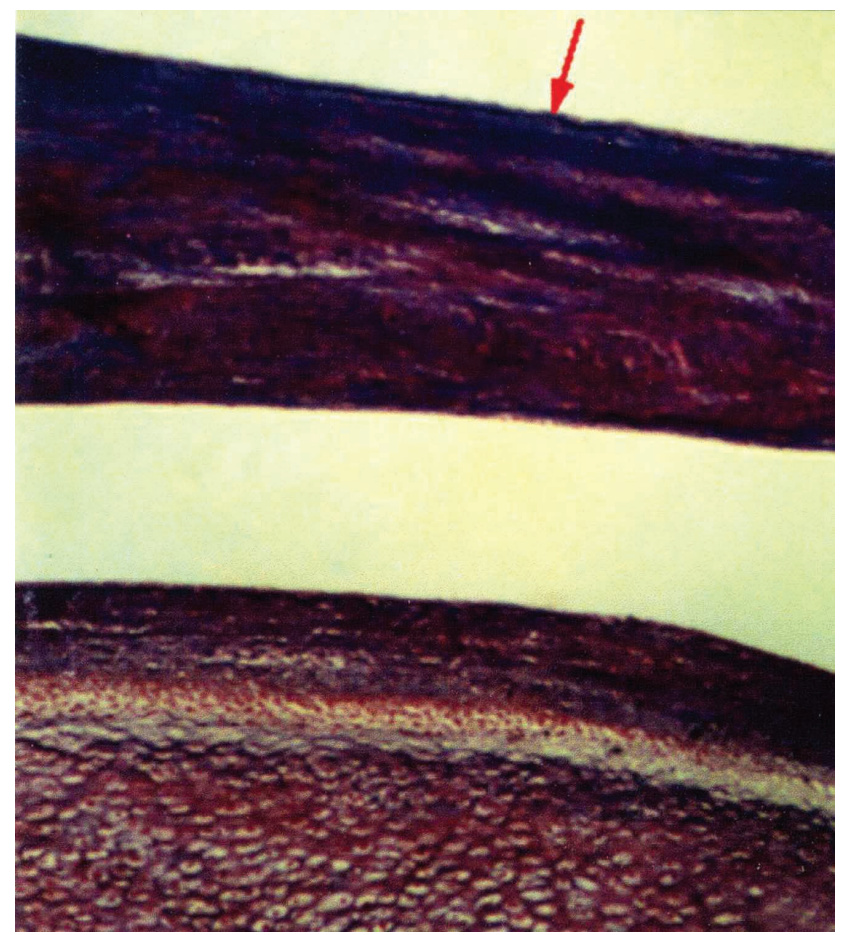

Fig. 1. Fetus with 36 weeks of intrauterine life. Articular disc (arrow). 90X.

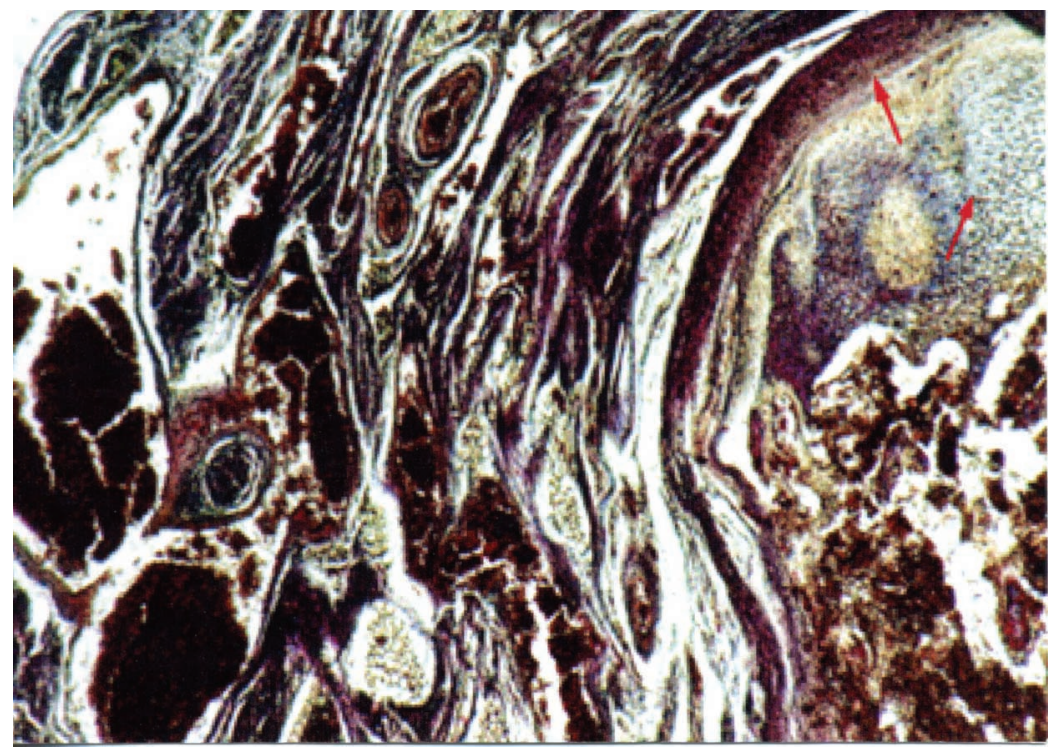

Fig. 3. Fetus with 36 weeks of intrauterine life. Condylar process and articular covering (arrows). 40X.
The articular capsule was already well defined in the fetuses with 16 weeks of intrauterine life. Formed by fibrous connective tissue with spaces between the fiber bundles, which gave it a loose aspect providing it a good mobility (Fig. 2).

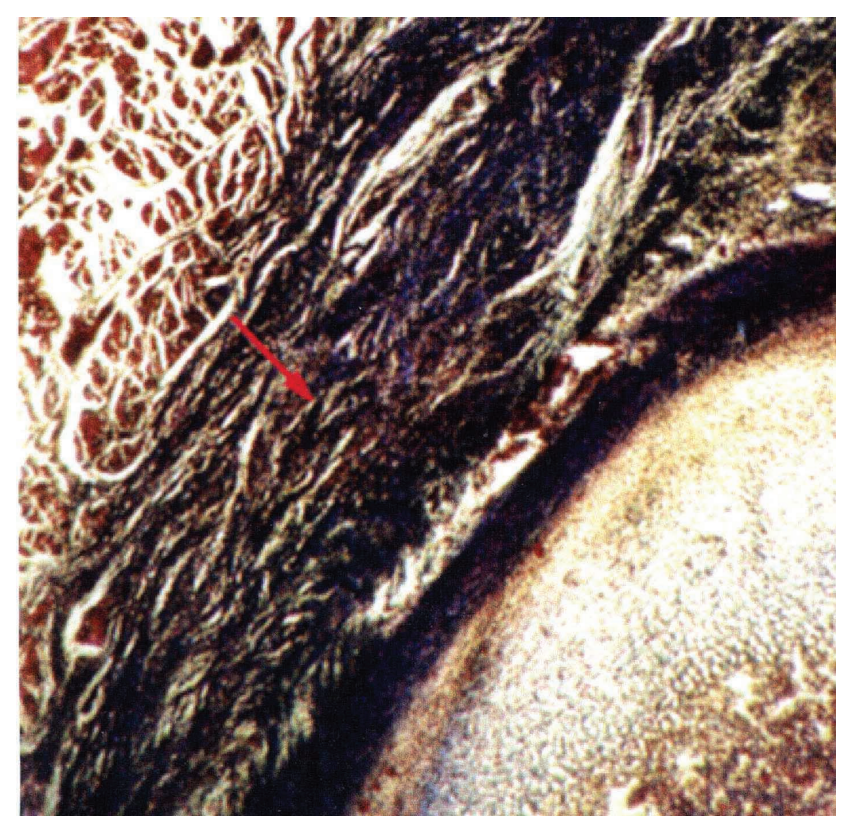

Fig. 2. Fetus with 16 weeks of intrauterine life. Articular capsule (arrow). 40X.
Regarding the condylar process what could be observed that it presented itself formed predominantly by a cartilaginous tissue and was thicker in younger fetus. It could be observed some odontoblasts invading the cartilaginous tissue. The amount of odontoblasts got higher proportionally to the increase in age. Covering all its extension we could observe fibrous cells with cartilaginous tissue since the $16^{\text {th }}$ week of intrauterine life (Fig. 3).

We could also observe since the $16^{\text {th }}$ week of intrauterine life that the lateral pterygoid muscle appeared intimately related with articular capsula and with the articular disc, sending fibers to the periphery of them (Fig. 4). 


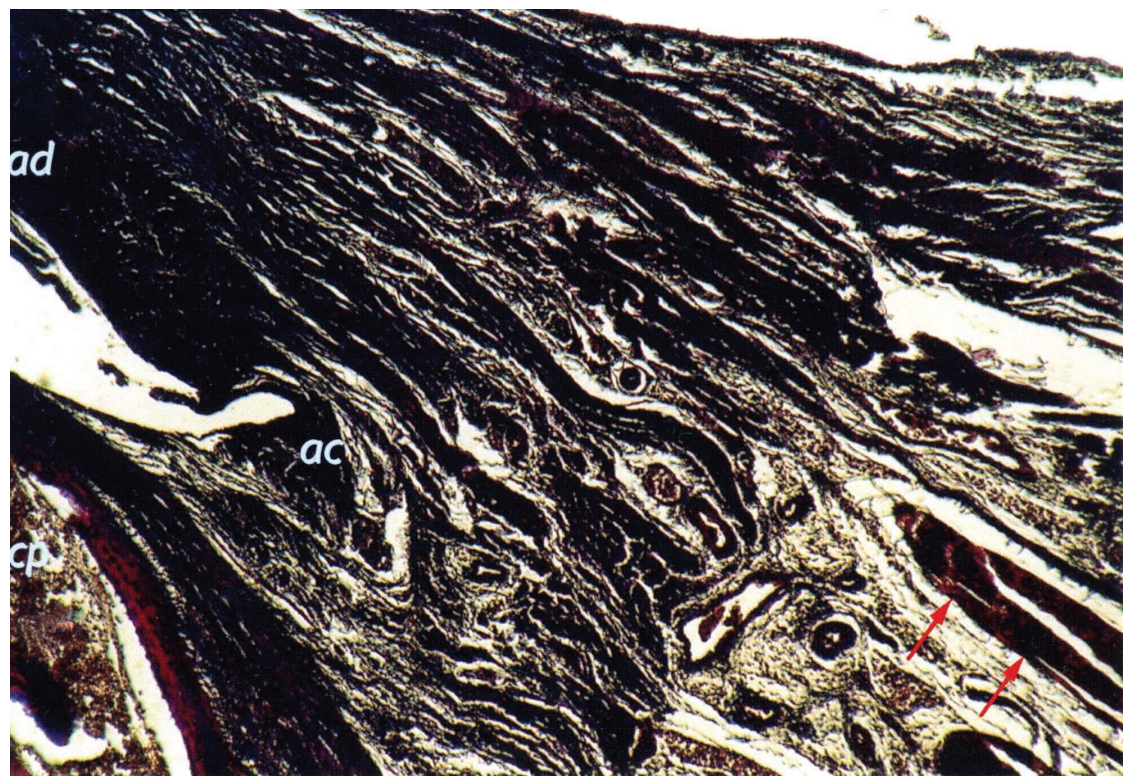

Fig. 4. Fetus with 16 weeks of intrauterine life. Muscular fibers (arrows); articular capsule (ac); articular disc (ad); condylar process (cp). 40X.
We could observe in the $24^{\text {th }}$ week of intrauterine life a higher organization of the cartilaginous cell from the condylar process. The covering fibercartilaginous from the condylar process presented a higher amount of fibrous connective tissue. The fibers of connective tissue of the articular disc were stretched, the opposite was observed in the younger age. This is probably due to the action of the superior head of the lateral pterygoid muscle that, inserted in the anterior edge of the disc traction it previously during the mandibular movements (Fig. 5).

\section{DISCUSSION}

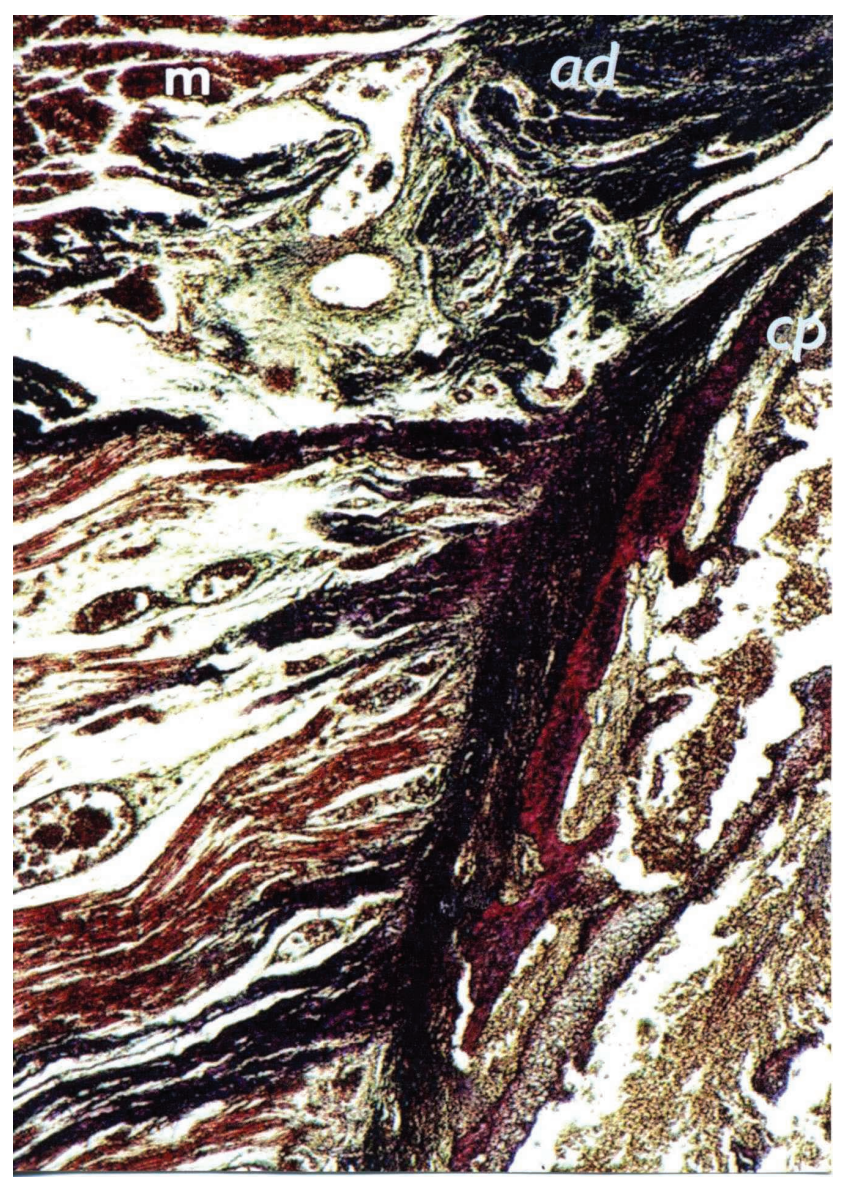

Fig. 5. Fetus with 24 weeks of intrauterine life. Lateral pterygoid muscle, superior head (m); articular disc (ad); condylar process (cp). 40X.
The results obtained in our work are in accordance with the ones of Symons (1952), once that observations done in an age range near to the one he studied, showed the articular disc well defined.

We also agree with Morimoto et al. (1987) who say that the articular disc was distinguishable and was composed of fine collagen fibers at the fifteenth gestacional week. In our work we could observe that the insertion of the lateral pterygoid muscle through its superior head occurs in the articular disc and in the articular capsule, in all studied ages.

We agree with Symons, Baume (1962), Wong et al. (1985), Ogütcen-Toller \& Juniper (1993), Mérida-Velasco et al. (1993), Minarelli \& Liberti (1996), Radlanski et al. (1999), when affirm that the lateral pterygoid muscle in fetuses inserts itself in the articular disc . We also agree with Wierusz \&Wozniak (2004) when relate that in fetuses of 9 and 10 weeks, the articular disc is connected with the articular capsule and lateral pterygoid muscle.

Our results are in accordance with the ones of Carranza et al. (2006). They affirm that their results suggest that between 16 and 22 weeks of gestation the differentiation and maturation process of the muscle fibers precedes and prevails over the development and mineralization process from condylar process. The rudimentary performance of the prenatal lateral pterygoid muscle would be of the factors that regulate the process of ossification at the level of the condylar process. The rate of ossification would increase starting from $22^{\text {th }}$ week of gestation. 
Mérida-Velasco et al. (1999) affirm that the critical period of morphogenesis of the temporomandibular joint occurs between the $7^{\text {th }}$ and $11^{\text {th }}$ week of development. These authors studied through the optic microscopy, 25 embryos and 45 fetuses with ages varying from 7 to 17 weeks of development. Therefore a younger age range than the one used in our study.

Morimoto et al. affirm that $21^{\text {th }}$ week seemed to be the greatest turning point of the prenatal development of the human temporomandibular joint. In our work we could observe that from the $24^{\text {th }}$ week of intrauterine life there was a higher organization of cartilaginous cell in the condylar process. The overlay fibercartilaginous of the condylar process presented a higher quantity of connective fibrous tissue. The fibers of connective tissue of the articular disc presented themselves stretched, the opposite could be observed in the lower ages. This is due to the action of the superior head of the lateral pterygoid muscle that inserted in the anterior portion of the disc traction it anteriorly during the mandibular movements.

Regarding the comments above, the following conclusions were obtained: the fibers and the thickness of the articular disc, as well as, the articular capsule and the condylar process, suffer modifications according to age; the superior head of the lateral pterygoid muscle is inserted in the disc and in the articular capsule, in all the studied ages; the maturation of the articular tissues, in special the articular disc, as well as, the associated muscles suggest that the TMJ was capable of doing mandibular movements from the $24^{\text {th }}$ week of intrauterine life.

ALVES, N. Estudio del desarrollo de la articulación témporomandibular en fetos humanos. Int. J. Morphol., 26(2):309-312, 2008.

RESUMEN: La articulación témporomandibular (ATM) es una articulación altamente especializada que se distingue de todas las otras articulaciones sinoviales por muchas razones. En los niños, a diferencia de lo que se observa en los adultos, estas articulaciones muy pocas veces han sido estudiadas en el aspecto morfofuncional, principalmente, en las etapas embrionaria y fetal. Se utilizaron 10 fetos con edades que variaban entre 16 a 39 semanas de vida intrauterina. Se pudo observar que las fibras y espesor del disco articular, así como la cápsula articular y el proceso condilar, sufren modificaciones en función de la edad. También se observó que la parte superior del músculo pterigoideo lateral se inserta en el disco y en la cápsula articular en todas las edades estudiadas. Por otra parte, la maduración de los tejidos articulares, especialmente del disco articular, así como, de los músculos asociados, sugiere que la ATM es capaz de llevar a cabo los movimientos mandibulares, desde la $24^{\text {a }}$ semana de vida intrauterina.

PALABRAS CLAVE: Articulación temporomandibular; Desarrollo embrionario; Desarrollo fetal.

\section{REFERENCES}

Alves, N. \& Cândido, P. Anatomia para o curso de Odontologia geral e específica. $1^{\text {a }}$ ed. São Paulo, Santos, 2007.

Baume, L. J. Ontogenesis of the human temporomandibular joint. Development of the condyles. J. Dent. Res., 41:1327-39, 1962.

Carranza, M. L.; Carda, C.; Simbrón, A.; Quevedo, M. C.; Celaya, G. \& de Ferraris, M. E. Morphology of the lateral pterygoid muscle associated to the mandibular condyle in the human prenatal stage. Acta Odontol. Latinoam., 19(1):29-36, 2006.

Mérida-Velasco, J. R.; Rodriguez-Vázquez, J. F. \& Jimenez-Collado, J. The relationships between the temporomandibular joint disc and related masticatory muscles in humans. J. Oral. Maxillofac. Surg., 51(4):390-5, discussion 395-6, 1993.

Mérida-Velasco, J. R.; Rodríguez-Vázquez, J. F.; Mérida-Velasco, J. A.; Sánchez-Montesinos, I.; Espín-Ferra, J. \& Jiménez-Collado, J. Development of the human temporomandibular joint. Anat. Rec., 255(1):20-33, 1999.

Minarelli, A. M. \& Liberti, E. A. Relação entre o feixe superior do músculo pterigóideo lateral e o disco da ATM humana: estudo ao microscópio de luz. Rev. Odontol. Univ. São Paulo, 10(3):1759, 1996.

Morimoto, K.; Hashimoto, N. \& Suetsugu, T. Prenatal development process of human temporomandibular joint. J. Prosthet. Dent., 57(6):723-30, 1987.
Ogütcen-Toller, M. \& Juniper, R. P. The embryologic development of the human lateral pterygoid muscle and its relationships with the temporomandibular joint disc and Meckel's cartilage. J. Oral Maxillofac. Surg., 51(7):772-8; discussion 778-9, 1993.

Radlanski, R. J.; Lieck, S. \& Bontschev, N. E. Development of the human temporomandibular joint. Computer-aided 3Dreconstructions. Eur. J. Oral Sci., 107(1):25-34, 1999.

Symons, N. B. The development of the human mandibular joint. $J$. Anat., 86(3):326-32, 1952.

Wierusz, A. \& Wozniak, W. Early fetal development of the articular disc in the human temporomandibular joint. Folia Morphol. (Warsz), 63(2):185-8, 2004.

Wong, G. B.; Weinberg, S. \& Symington, J. M. Morphology of the developing articular disc of the human temporomandibular joint. J. Oral Maxillofac. Surg., 43(8):565-9, 1985.

Correspondence to:

Dr. Nilton Alves

Departamento de Morfologia

Faculdade de Odontologia de Araraquara, UNESP

Rua Humaitá, 1680

CEP: 14.801-903 Araraquara - São Paulo - BRASIL

E mail: niltonnalves@hotmail.com Received: 05-10-2007

Accepted: 22-01-2008 